\title{
УДК 811.161.2'366.56'367
}

Наталія Ясакова

\section{МИ ЗАМІСТЬ Я: СЕМАНТИКА І ПРАГМАТИКА}

У статті проаналізовано семантико-прагматичні варіанти значення першої особи, щяо виникають унаслідок взаємодії категорій персональності та числа. Виокремлено ми авторське, царське, скромне, родинне, батьківське (опікунське), корпоративне, ми соиіальної вагомості, ідеологічне, універсальне (філософське), ми привілейованої групи.

Ключові слова: категорія персональності, семантика, прагматика, семантико-прагматичний варіант, перша особа, мовець.

Мовознавці здавна відзначали функціонування в мовленні особливих варіантів значень першої особи, зокрема, називаючи ми авторське, ми царське тощо [Benvenist : 268-269; Himik : 115-116; Sulyma : 21]. Однак найчастіше зусилля науковців були спрямовані не на типологію та інтерпретацію різних видів указувань мовця на самого себе, а на розв'язання інших завдань: систематизацію морфологічних форм, дослідження категорії числа, стилістичних функцій експлікаторів персональних значень у тексті тощо. Зокрема, у працях із морфології авторів передусім цікавило розмежування первинних і вторинних функцій займенникових іменників та дієслівних форм. 
Систематизація й інтерпретація прагматично вмотивованих уживань, чинники, що зумовлюють вибір певного способу вказування на мовця чи співрозмовника, переважно залишалися поза увагою, оскільки не відповідали завданням таких досліджень.

Типологія адресантності, яку запропонував російський мовознавець В. Хімік, є надто загальною й непослідовною, оскільки релевантними для виокремлення груп виступають різні критерії. Учений називає чотири субкатегорійних типи адресантності: а) абсолютна адресантність (Я не сплю), б) інклюзивна адресантність $(я+m u, \quad+6 u, \quad x+$ він тощо), в) ритуальна адресантність (авторське, скромне, царське, просторічно-представницьке ми), г) експресивна адресантність (Кому кажуть!) [Himik :115-116].

Багатство значень, що приховується за вживаннями ми в різних комунікативних ситуаціях, залишається не висвітленим. Отже, немає чіткого розуміння однієї з основних функцій людини, що вирізняє ії 3-поміж інших істот і безпосередньо пов'язана з буттям мови, - функції мовця.

Мета цієї розвідки - систематизувати семантико-прагматичні варіанти значення першої особи, що виникають унаслідок взаємодії категорій персональності та числа.

Функційна специфічність особи як актуалізаційної категорії дейктичного типу, поняттєві особливості першої особи, різноманітність соціальних функцій людини втілюються у варіантах категорійного значення першої особи. Мовець не тільки вказує на себе як суб'єкта, об'єкта чи адресата названої дії, але й висловлюється про цілий клас осіб, до яких належить. Відповідно розрізняють референтні та нереферентні вживання особових займенникових іменників [Graneva 2008 : 208]. У разі референтного вживання займенниковий іменник стосується осіб, які є безпосередніми учасниками комунікації i, отже, можуть бути об’єктами конкретної референції. Безумовно, ця функція $є$ для них первинною.

Найчастіше для вказування на себе мовець послуговується займенником першої особи або дієслівною формою першої особи. Ці мовні одиниці виступають центральними експлікаторами відповідної семантики, що найчіткіше ідентифікують мовця як активного учасника комунікативного акту, мають найширше вживання i, на відміну від їхніх функційних аналогів, для яких референція до мовця є вторинною, переважно не супроводжуються додатковими відтінками значення.

Низка прагматичних варіантів семантики першої особи, що, крім власне дейктичної функції вказування на мовця, передають додаткову інформацію щодо його соціальних функцій, експлікуються завдяки тісній взаємодії категорій персональності та числа. У різних мовленнєвих ситуаціях ті самі форми першої особи множини мають відмінне функційне навантаження. 
Окремим способом референції до мовця $\epsilon$ авторське ми, характерне передусім для наукового дискурсу, напр.: Розрізняємо три основних рівні поліфонізму мови прози... (С. Бибик). Авторське ми бачимо також у художніх і публіцистичних текстах, напр.: Коли б ішлося тільки про полювання та про екзотику, ми б тобі, читачу, розповіли, як мисливцуі наші здобували рисів, ловили колонків та солонгоїв, капканили вовків... (І. Багряний); Ми вже говорили про готовність поета до упокорення (В. Базилевський).

I. Матвіяс зазначає, що авторське ми трапляється ще в античних мовах, у руських літописах приклади його вживання бачимо вже у XII ст. [Matviyas : 19]. Використання форм множини для вказування на автора тексту характерне не тільки для української мови, а й інших, зокрема німецької, російської [Kordić : 147; Uspenskij : 27]. Водночас у сучасній англомовній науковій літературі авторське ми майже не вживають. В. Карасик пов'язує це з тим, що загальний стиль наукового викладу в працях американських, британських, канадських дослідників вільніший, ніж у подібних працях мовознавців радянської школи, що засвідчують, зокрема, особисті присвяти, неформальні подяки й особиста інформація в передмовах [Karasik : 227].

Уживання в науковому тексті ми замість я пояснюють по-різному, зокрема й прагненням пом'якшити дискусію [Kordić : 147]. В’яч. Іванов уважає, що функціонування множини в наукових працях зумовлене тим, що суб'єктомавтором висловлювання в сучасних наукових текстах найчастіше є ціла група осіб, а також тим, що кожна праця повинна враховувати досвід попередніх досліджень з певної теми [Ivanov : 556].

У науковому дискурсі, зокрема в письмових текстах, усних доповідях, дискусіях, уживання множини замість однини регламентоване традицією й підтримується загальним спрямуванням до об'єктивації змісту. Автор художнього або публіцистичного текстів менше зважає на традиції, має ширші можливості самопрезентації за допомогою різних експлікаторів граматичної семантики персональності. У науковому тексті авторське ми конкурує 3 повністю знеособленим поданням результатів діяльності мовця, пор.: Термінативність визнано ядерною зоною, а всі іниі субкатегорії розташовано за принцииом зменшення кількості ознак... (М. Калько) - Термінативність визнаємо ядерною зоною, а всі інші субкатегорії розташовуємо за принципом зменшення кількості ознак... Натомість характерна для публіцистичного й художнього текстів суб’єктивність нерідко втілюється в оповіді від першої особи, де автор указує на себе за допомогою займенникового іменника першої особи однини або відповідної форми дієслова, напр.: $\underline{\underline{A}}$ автор, щзо так невдало переказую оповідання Кіндрата Осики, бачу живого діда Чумака в недобіленій, сірій сорочці... (Г. Косинка); Пильнуймо, пані та панове. Це тільки початок, $\underline{\text { }}$ так думаю (Український тиждень, № 11 (228), 2012). Авторське ми (pluralis 
auctoris) може виражати як асоціацію, так і дисоціацію автора та читацької аудиторії: з одного боку, воно може об'єднувати автора з читачем, а з другого може виражати вилучення автора $з$ діалогічної ситуації. Форма першої особи множини в принципі не передбачає в цьому випадку вживання форми другої особи множини (pluralis reverentiae) [Uspenskij : 27].

3-поміж виявів авторського ми в текстах усіх згаданих стилів виокремлюємо випадки, коли множина першої особи виступає традиційним прагматичним варіантом першої особи однини, тобто експлікатор відповідного значення вказує тільки на мовця, якому властива специфічна соціальна функція автора тексту, напр.: Скажемо тільки: Віктор Довбиш - великий майстер свого діла (Г. Тютюнник); Наводимо зразок побутового літературного мовлення кінияя 50-x років XIX cm. (М. Пилинський). Лише в такому разі референція здійснюється до однієї особи - мовця.

У низці випадків ми є інклюзивним - стосується не тільки автора, а й читача як співрозмовників і своєрідних свідків або співучасників описуваних подій, напр.: ...а ми подивимось, де то Антосьо обертасться; вже ж n'ять літ, як ми бачили його (А. Свидницький); Сам заголовок змушує нас думати про аналогї релігійного характеру (О. Ольжич). На думку В. Хіміка, таке значення передбачає певну неозначеність осіб, що належать до вказаного угруповання, а також актуалізацію адресатної функції суб’єкта за рахунок певного послаблення ролі мовця, що засвідчує можливість заміни ми на ви, напр.: У периих рядках віриа ми бачимо яскраву метафору. - У периих рядках вірша ви бачите яскраву метафору. Реалізацію такої семантики уможливлюють уживані в тексті прямі вказування на узагальненість адресата, наприклад, звертання на зразок дорогий читачу, лексеми й дієслівні форми другої особи, засоби вираження спонукальності. Учений відзначає також іншу особливість такого інклюзивного ми - нейтралізацію протиставлення одиничності / множинності адресатів: у конкретній ситуації актуалізований адресат може співвідноситись і з одиничним, і з множинним денотатом [Himik : 43].

Для художнього й публіцистичного стилів таке ми є засобом інтимізації оповіді. У науковому дискурсі інклюзивне ми виступає інструментом об'єктивації, оскільки автор долучає читача або слухача до власних спостережень і висновків, напр.: Як приклад розглянемо узагальнення в теорії груп понять «одиниця» («одиничний елемент») $i$ «добуток» (М. Попович). Таку саму функцію ми може виконувати і в публіцистичному тексті, напр.: Якщзо $\underline{\text { мu }}$ подивимося на формування німецьькӧ̈, італійської та кількох інших європейських націй, то цеей прочзес відродження чи творення їх у XIX столітті почався як реакція на програні війни, національні принижсення... (Український тиждень, № 17-18 (337-338), 2014). 
Формування авторського ми інклюзивного, у якому діалогічність уможливлена залученням уявного адресата до пояснення, Г. Наєнко відзначає в наукових текстах середньоукраїнського періоду (XVI-XVIII ст.). Така модель задається перекладними зразками, що поширювалися в навчальних закладах. Як визначальна для академічного дискурсу, вона притаманна й латиномовним навчальним курсам Києво-Могилянської академії, зокрема i в Стефана Яворського, i в Георгія Кониського [Nayenko : 121-122]. Нині вживання інклюзивного мu, коли виконавцем дії $є$ мовець, який намагається залучити адресата (адресатів) мовлення до активного сприйняття своїх дій, характерне для педагогічного дискурсу, напр.: Розв'яжемо наступну задачу; Змоделюємо іниу ситуаиію.

На протиставлення мовця й співрозмовника спрямоване так зване царське ми (pluralis majestatis). Воно покликане акцентувати винятково високий соціальний статус мовця, дистанцію між комунікантами, а також засвідчувати офіційність ситуації мовлення, напр.: В о є в о да: Пан писарю, негайно напиши // В конвент домініканський, до абата, // Отия Ієроніма, щзо його // Ми просимо прийнять дружину нашу (І. Кочерга). Царське ми вживають у разі офіційного застосування владних повноважень. Особа, наділена ними, не завжди послуговується саме таким способом указування на себе. У неофіційній ситуації, зокрема емоційному мовленні, та сама особа вживає форму самопрезентації, позбавлену додаткових значень, напр.: Восвода (розлючений, стукає кулаком об стіл) Тут я закон, і князь, і воєвода, // Не табір тут козацький на степу, // Де кожен кмет свій голос має в раді. // Тут я один сам знаю, шзо роблю (І. Кочерга).

У Свропі царське ми з'явилося в Римі у III ст. н. е., коли державу очолювали одразу кілька імператорів. Воно збереглося в період одноосібного правління і стало традицією, яку засвоїли в інших країнах [Majtinskaja : 156], зокрема, на Русі таку форму використовують з XIV століття, очевидно, під упливом латини. Водночас наявність pluralis majestatis у мовах, які не мають жодного стосунку до європейської традиції, засвідчує можливість пояснювати це явище типологічно, а не історично [Uspenskij : 79]. Сумнівним $\epsilon$ потрактування І. Граневою ми царського як історичного різновиду ми письменницького (ми оповідача), як і думка про те, що нині pluralis majestatis трансформувалось у ми «начальницьке», напр.: Мu вас звільняємо [Graneva 2009 : 16]. Уживання ми замість я у спілкуванні начальника й підлеглого є виявом ми іншого типу, що демонструє належність мовця до певної соціальної групи. У сучасній українській мові царське ми вживають рідко, його можна вважати граматичним історизмом.

У більшості випадків уживання ми замість я засвідчує залучення до особистої сфери мовця інших осіб. Множинна форма допомагає уникнути 
некомфортної для адресанта мовлення індивідуалізації або подати висловлювану думку як офіційну позицію певного кола осіб, яке він представляє. Вибір множинної форми може бути зумовлений i бажанням зменшити увагу до власної особистості, і прагненням надати собі більшої соціальної ваги. У першому випадку можна говорити про реалізацію різновидів скромного ми. За допомогою множинної форми мовець намагається уникнути комунікативної унікальності, виразної протиставленості $я$ іншим особам, наголосити численність тих, хто перебуває або може опинитись у подібній ситуації, напр.: Гр и из к о. Та знаєте... зайшла річ за таку персону, щзо нам уже і підступити страшно (М. Старицький).

Таке применшення власної значущості характерне для спілкування осіб у разі виразної соціальної нерівності. Зокрема, в повісті Г. Квітки-Основ’яненка «Щира любов» простий чоловік Олексій Таранець під час першої зустрічі 3 офіцером Семеном Івановичем, окрім невербальних виявів визнання безумовної соціальної вищості адресата, вживає і ввічливе ви, і ми замість я: Олексій, як треба, зараз скочив, поклонився охвищеру звичайно та й хотів дальше відійти, бо не приходилося мужикові рівнятися з його благородієм. <..> - Та ні, поклонившися вп'ять, сказав Олексій. - Вже нам не подоба проти вас

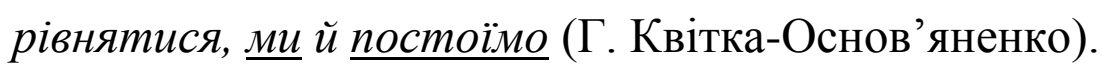

Подаючи себе як одного з багатьох осіб, мовець применшує не лише власну соціальну значущість, а й відповідальність за певні вчинки та слова, напр.:

- ...ие ж пекло, тату! Невже ти не відчуваєи? I щзо робим у ньому, такий благий та мудрий?

- Вахтьори 쓰, - повідомив старий (Ю. Андрухович).

3 такою самою метою мовець може вживати ми інклюзивне: він подає дію, що виконує сам, як спільну 3 адресатом мовлення, поділяючи 3 ним i відповідальність за помилки. Так висловлюється, наприклад, член приймальної комісії в оповіданні В. Шкляра, коли з'ясовує, що повідомила абітурієнтові не його оцінку за іспит:

- Так ми ж з вами не туди дивилися.

Теж мені, «ми з вами...». Я нікуди не дивився (В. Шкляр).

Уживання ми замість я актуалізує належність мовця до родини, коли він виступає їі представником, зокрема в ситуаціях запрошення до господи, двору або столу, напр.: - Просимо, просимо, пане добродію! - каже Гвинтовка. - I сіни, й хата перед тобою настіж (М. Куліш). Таке родинне ми особа може вживати й тоді, коли не перебуває в колі родини і не виступає їі представником, напр.:

- Просимо вечерять! - промовив чоловік, виймаючи з торби окраєцьь хліба, сіль та изибулю. 
- Вечеряй на здоров'я! - промовили бурлаки (І. Нечуй-Левицький).

У наведеному уривку з повісті «Микола Джеря» Андрій Корчака запрошує Джерю та його товаришів вечеряти, вживаючи множину, хоча суб'єктом дії є тільки він сам. Мовець використовує форму, яку часто вживають у подібних ситуаціях, коли до столу запрошують у власному домі і ми вказує на мовця та інших членів родини.

$M u$ замість $я$ у розмові вживають і для наголошення власної соціальної вагомості, обізнаності, досвідченості, що безпосередньо не пов'язані $з$ певною

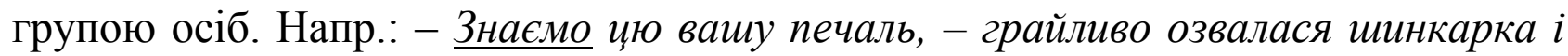
жартома пригрозила мені пальцем (В. Шевчук). Таке ми увиразнює протиставленість комунікантів, акцентує дистанцію між ними.

Іншу функцію виконує ми в спілкуванні дорослих із маленькими дітьми або хворими, дуже літніми людьми: множина уможливлює зближення комунікантів. Дія подається як спільна, хоча реальним іiі виконавцем є тільки мовець, напр.: - Зараз намалюсмо веселішого [чоловічка]. Стерла [мати], хукнула в іншому місиі, повела пальщем по колу (А. Дімаров). Таке залучення до власних дій адресата мовлення водночас увиразнює його соціальну несамостійність. Тому вживання батьківського (опікунського) ми може сприйматись як недоречне, образливе, таке, що засвідчує неспроможність співрозмовника.

Коли мовець виступає офіційним представником певної організації, хоче акцентувати свою причетність до неї, реалізується $м и$ корпоративне, напр.: - Як ти вчився, ми зиаємо, - директор [школи] тяжкко ци утомлено зітхнув (В. Слапчук); Оскільки ми прачюємо як галерея мистецтв, то постійно бачимо живопис, графіку, фото різного рівня (День, 06-07.02.2015).

Належність до певної спільноти мовець може розцінювати як перевагу над співрозмовником. Уживанням ми мовець акцентує свій стосунок до певної привілейованої групи осіб, указує на те, що важливою є не його особиста позиція, а інтереси цієї впливової групи. Таке ми бачимо в мовленні різноманітних представників радянських владних і каральних структур, напр.: Дурню ти! Ми тебе можемо засудити й без твоєї сповіді! (I. Багряний); Але мии терплячі. Ніхто не є такий терплячий, як радянська влада і ї̈ представники! (M. Матіос). Часткова неозначеність ми уможливлює вільне потрактування і якісного, і кількісного складу групи осіб, до якої мовець зараховує себе. Акцентовано передусім іï численність і представницьку роль мовця, який має владні повноваження й не несе особистої відповідальності. Заперечення з боку слухача в такому разі інтерпретуються як адресовані не одній особі, а всій тій групі, представником якої виступає мовець. Уживаючи ми замість я, мовець експлікує свій вищий комунікативний статус. 
Послаблення індивідуальних рис мовця в разі вживання множинних форм призводить до їхнього активного функціонування в маніпулятивній комунікації. Зокрема, деперсоналізоване ми замість $я$ часто виступає в політичному, ідеологічному, публіцистичному дискурсах для ототожнення поглядів автора 3 поглядами адресата, залучення його до сфери своїх ідей та цінностей [Graneva 2009 : 23]. Традиція вживання $м и$, форм третьої особи або й неозначено-особового речення, коли діячем є мовець, свідчить про те, що в певному соціумі не схвалюють вираження індивідуальної позиції. Таке уникання $я$, зокрема, було поширене за радянських часів як засіб демонстрації пріоритету колективної думки та нівелювання особистої відповідальності мовця. Пор.: $C$ пропозиція розпочати збори - Пропоную розпочати збори; $Я$ ухвалив рішення - Ухвалено рішення.

Уживання ми в тоталітарному дискурсі уможливлює реалізацію таких важливих ознак, властивих його мові, як ілюзія участі слухача в названих діях, поляризація, створення образу ворога. Типізацію людини, вбудовування іiі до певної узагальненої схеми (етнічної, гендерної, соціальної), нейтралізацію індивідуальності вважають характерними рисами тоталітарної мови [Gronskaja : 59]. Невизначена множинність ми, що охоплює мовця та слухачів або й необмежену кількість третіх осіб, підтримувана контекстом, ситуацією мовлення, набула особливого значення в промовах, публіцистичних або й художніх текстах радянської доби.

Основною сферою функціонування радянського зразка тоталітарної мови вважають газетно-публіцистичний дискурс. Ужите в тексті газетної передовиці ми створювало враження численності чітко не названої, поєднаної за ідеологічними ознаками групи осіб, до якої належить автор тексту. Таке ідеологічне $м и$ стосувалося всіх громадян водночас, отже, читач відчував свою причетність до описаних подій, названих дій та оцінок. Водночас уживання займенникового іменника першої особи, що на поняттєвому рівні протиставлений третій особі, увиразнювало опозицію пропагованих і «класово» або «ідеологічно чужих» поглядів та цінностей, актуалізувало поляризовану картину світу, яка чітко поділена на ми і вони.

Коли ми не стосується ситуації безпосереднього спілкування, воно не співвіднесене з референтом, отже, не виконує власне дейктичної функції. У такому разі встановлення його змісту потребує звернення до фонду знань слухача або читача. Такому ми не властива конкретна референція, воно стосується адресанта мовлення лише опосередковано, оскільки мовець зараховує себе до певної групи осіб, напр.: $\underline{M u}$ ганьбили Твория на землі (В. Герасим'юк).

Такі нереферентні вживання $м и$ поділяють на три типи: екзистенційне $м и$, що окреслює певний клас осіб зі спільними поглядами, переконаннями тощо, 
універсальне $м и$, що вказує на множину всіх осіб, і родове $м и$, яке стосується чітко позначеного класу осіб [Graneva 2009 : 12-13]. Лише в останньому випадку групу людей, до якої зараховує себе мовець, називає повнозначний іменник, напр.: Нам, хліборобам, що з мечем почати? (І. Франко); $\underline{\mathrm{Ha \mu}}$, металургам, не личить чвари розводити (О. Гончар).

Часто група осіб, до якої вважає себе причетним мовець, не названа, проте зрозуміла читачеві або слухачеві завдяки контексту або спільному з мовцем фонду знань. Саме так ідентифікується зміст універсального й екзистенційного ми. Універсальне $м и$ називають також філософським, оскільки концептуалізація відповідного прономінатива характерна для філософського осягнення людини усвідомлення iї сутнісних рис. Висловлювання із філософським ми, що стосуються будь-якої людини, отже, й кожного з учасників комунікації, близькі до узагальнено-особових, однак відмінні від них загальною універсальністю змісту. Напр.: Ми від народження берем правічний гріх (В. Стус); Рятуючи себе, ми рятуємо иілий світ (Г. Пагутяк). Узагальненість граматичної особи засвідчує передусім нерелевантність персонального статусу суб'єкта в межах певного комунікативного акту: предикативна ознака може стосуватись і мовця, і співрозмовника, когось із третіх осіб, але не обов'язково властива водночас усім людям.

Як указує Ф. Бацевич, механізми дейксису й анафори зазвичай тісно пов'язані зі спільними для всіх носіїв певної лінгвокультури або громадян якоїсь держави пресупозиціями різних типів [Bacevych : 130]. Останні важливі передусім для розуміння екзистенційного ми, яке називають також ціннісним, ідеологічним [Graneva 2008 : 209]. Ми в тому самому реченні в різні періоди життя суспільства наповнюється відмінним змістом. Зокрема, різне розуміння ми характерне для висловлювання $М$ ие переможемо в умовах Другої світової війни й сучасної України. Якщо в першому випадку ми стосувалося громадян СРСР, то в другому - громадян України.

Отже, у творенні низки семантико-прагматичних різновидів категорійного значення першої особи бере участь граматичне значення множини. У такому разі форма множини часто не відбиває реальної кількості осіб, а засвідчує наявність додаткових, прагматично зумовлених значень, що стосуються мовця в контексті певного комунікативного акту. Уживання $м и$ замість $я$ відповідно до умов спілкування та намірів мовця уможливлює як акцентування його виняткової соціальної функції та комунікативного статусу (царське ми), так і зневиразнення ролі мовця як окремої індивідуальності (різновиди скромного ми), що, проте, не завжди означає зниження його комунікативного статусу. Поза умовами ситуації міжперсонального спілкування формується особлива функційна сфера нереферентного вживання $м и$, що опосередковано стосується 
мовця. $М и$ вказує на кількісно необмежену групу людей, об’єднаних за певною ознакою, до якої причетний і мовець.

Вивчення способів самореференції мовця, що притаманні українській мові, сприятиме встановленню когнітивно-комунікативних характеристик картини світу, аналізу дискурсів різного типу. Плідним буде й дослідження в цьому аспекті текстів різних стилів і жанрів.

\section{References}

Bacevych F. S. Narysy z linhvistychnoyi prahmatyky (Essays on linguistic pragmatics). L'viv: PAYIS.

Benvenist, Emile. Obshchaia lingvistika (General linguistics). Moskva: Editorial URSS, 2002.

Graneva, Irina. "Mestoimenie my v sovremennom russkom jazyke: kommunikativno-pragmaticheskij podhod (The pronoun in modern Russian)." Diss. Lobachevsky University of Nizhni Novgorod, 2009. Abstract.

Graneva, Irina. "O referentnom i nereferentnom upotreblenii mestoimenija my (On the reference and non-referential use of the pronoun мы)". Vestnik Nizhegorodskogo universiteta im. N. I. Lobachevskogo. Filologija. Iskusstvovedenie (Vestnik of Lobachevsky University of Nizhni Novgorod. Philology. History of Art) 4 (2008): 206-209.

Gronskaja, Natal'ja, and Valerij Zusman, and Tat'jana Batishheva. "Sopostavlenie totalitarnyh diskursov: tri ritora, tri teksta, tri jazyka (Comparison of totalitarian discourses: three rhetoric, three texts, three languages)" [Virtual Resource] Vestnik Nizhegorodskogo universiteta im. N. I. Lobachevskogo (Vestnik of Lobachevsky University of Nizhni Novgorod) 1/2 (2013): 56-62. Access Mode : URL : http://www.unn.ru/pages/issues/vestnik/99999999_West_2013_1\%282\%29/11.pdf.

Himik, Vasilij. "Kategorija subjektivnosti $i$ ejo vyrazhenie $v$ russkom jazyke Category of the subjectivity and its expression in Russian”. Leningrad: Izd-vo Leningradskogo un-ta, 1990.

Ivanov, Vjacheslav. "Izbrannye trudy po semiotike i istorii kul'tury (Selected Works on Semiotics and Cultural History)”. Vol.1. Moskva: "Shkola Jazyki russkoj kul'tury”, 1998.

Karasik, Vladimir. “Jazyk social'nogo statusa (Language of social status)”. Moskva: Gnozis, 2002.

Kordić, Snježana. "Personal- und Reflexivpronomina als Träger von Personalität”. Personalitat und Person. Wiesbaden : Harrassowitz Verlag, 1999. 125-154.

Maytinskaya, Klara. "Mestoimenija v jazykah raznyh sistem (Pronouns in the languages of different systems).” Moskva: LIBROKOM, 2009.

Matviyas, Ivan. “Syntaksys zajmennykiv v ukrayinskij movi (Syntax of pronouns in Ukrainian)”. Kyiv: AN URSR, 1962.

Nayenko, Galy’na. “Adresantnist' naukovykh tekstiv seredn`oukrayins`kogo periodu (Addressing the scientific texts of the Middle Ukrainian period)" Ukrayins'ka mova (Ukrainian language) 2 (2012): 112-128.

Sulyma, Mykola. Ukrayins `ka fraza (Ukrainian phrase. Short essays) Kharkiv: Rukh, 1928.

Uspenskiy, Boris. "Ego Loguens: Jazyk i kommunikacionnoe prostranstvo (Ego Loguens: Language and communication space)." Moskva: Rossijskij gos. gumanit. un-t, 2007. 


\section{Abstract \\ Nataliya Yasakova \\ МИ IN PLACE OF $Я$ : SEMANTICS AND PRAGMATICS}

Background. Linguists and philologists have noted the functioning of specific versions of the meaning of the first person in speech for a long time, but most often the efforts of scientists were aimed not at the typology and the interpretation of different types of pointing of the speakers to themselves, but at solving other problems. The wealth of values hidden behind the use of $м u$ in different communication situations remains unclear.

Purpose. The purpose of this research is to systematize the semantic-pragmatic variants expressed by the first-person plural forms.

Methods. The descriptive method was used as the main one in the study, as well as the methods of distributional analysis, transformational analysis, discourse analysis.

Results. A separate way of referencing the speaker is the author's $m u$, which is typical, first, for scientific discourse. It is standardized by tradition and is supported by the general direction to objectivize the content. The royal $m u$ is aimed at emphasizing an exceptionally high social status of the speaker, the distance between the communicants, as well as certifying the officiality of the speech situation.

In most cases the use of $\boldsymbol{м u}$ instead of $я$ means the involvement of other people into the speaker's personal sphere. The plural form helps to avoid the uncomfortable personalization for the addressee or to submit the expressed opinion as an official position of a certain circle of persons that he/she represents. A special functional area of non-referential use of $\mathcal{M u}$, which is indirectly related to the speaker, is formed outside the conditions of the situation of interpersonal communication.

Discussion. The plural form often shows that there are additional pragmatically predetermined values related to the speaker in the context of certain acts of communication. The use of $м u$ instead of $я$ allows to emphasize its exceptional social function and communicative status, namely degenerating the role of the speaker as a separate individual, which does not necessarily mean reducing his/her communicative status.

The study of the speaker's self-referencing methods, which are proper to the Ukrainian language, will help to establish cognitive-communicative features of the global picture and to analyse different types of discourse.

Keywords: category of personality, semantics, pragmatics, the semantic and pragmatic option, first person, speaker. 